\title{
The Food and Beverage Occurrence of Furfuryl Alcohol and Myrcene-Two Emerging Potential Human Carcinogens?
}

\author{
Alex O. Okaru ${ }^{1,2}$ and Dirk W. Lachenmeier ${ }^{2, *}$ \\ 1 Department of Pharmaceutical Chemistry, University of Nairobi, P.O. Box 19676-00202, Nairobi, Kenya; \\ alex.okaru@gmail.com \\ 2 Chemisches und Veterinäruntersuchungsamt (CVUA) Karlsruhe, Weissenburger Strasse 3, \\ 76187 Karlsruhe, Germany \\ * Correspondence: lachenmeier@web.de; Tel.: +49-721-926-5434; Fax: +49-721-926-5539
}

Academic Editor: David Bellinger

Received: 23 December 2016; Accepted: 6 March 2017; Published: 11 March 2017

\begin{abstract}
For decades, compounds present in foods and beverages have been implicated in the etiology of human cancers. The World Health Organization (WHO) International Agency for Research on Cancer (IARC) continues to classify such agents regarding their potential carcinogenicity in humans based on new evidence from animal and human studies. Furfuryl alcohol and $\beta$-myrcene are potential human carcinogens due to be evaluated. The major source of furfuryl alcohol in foods is thermal processing and ageing of alcoholic beverages, while $\beta$-myrcene occurs naturally as a constituent of the essential oils of plants such as hops, lemongrass, and derived products. This study aimed to summarize the occurrence of furfuryl alcohol and $\beta$-myrcene in foods and beverages using literature review data. Additionally, results of furfuryl alcohol occurrence from our own nuclear magnetic resonance (NMR) analysis are included. The highest content of furfuryl alcohol was found in coffee beans (>100 mg/kg) and in some fish products (about $10 \mathrm{mg} / \mathrm{kg}$ ), while among beverages, wines contained between 1 and $10 \mathrm{mg} / \mathrm{L}$, with $8 \mathrm{mg} / \mathrm{L}$ in pineapple juice. The content of $\beta$-myrcene was highest in hops. In conclusion, the data about the occurrence of the two agents is currently judged as insufficient for exposure and risk assessment. The results of this study point out the food and beverage groups that may be considered for future monitoring of furfuryl alcohol and $\beta$-myrcene.
\end{abstract}

Keywords: furfuryl alcohol; $\beta$-myrcene; carcinogens; occurrence

\section{Introduction}

The production and processing of foods and beverages may invariably lead to significant changes in the chemical composition of the products. The Maillard reaction-which yields furanic compounds such as furfural and 5-hydroxymethylfurfural (HMF) and furfuryl alcohol, among other products - is common during processes that involve heating or roasting [1-5]. Furfuryl alcohol is a food contaminant which occurs in significant amounts in thermally processed foods such as coffee, fruit juices, baked foods; in cask-stored alcoholic beverages such as wines, wine-derived spirits such as brandy, and whiskies as a result of enzymatic or chemical reduction of furfural [6-8]; and in butter and butterscotch when furfuryl alcohol is used as a flavouring agent [9]. Furfuryl alcohol may also be formed from quinic acid or 1,2-enediols as precursors during the heating of foods such as coffee beans [5] . In acidic conditions, furfuryl alcohol polymerizes to aliphatic polymers that give a brown colouration to foods [5].

Myrcene is a terpenoid compound that exists in two forms $-\beta$ and $\alpha$, with the former occurring naturally in essential oils of plants such as hops, bay, lemongrass [10,11], and orange juice [12], 
and is permitted for use as a flavouring additive of food both by the United States Food and Drug Administration (FDA) since 1965 and by the European Council since 1974. $\beta$-Myrcene is also an ingredient in the preparation of olefinic scents such as menthol, and the alcohols linalool, nerol, and geraniol [13], found in household items.

Analysis of furfuryl alcohol can be done by either gas and liquid chromatography with UV, biosensor, or fluorescence detection [5,6,14-17], while $\beta$-myrcene is typically determined using gas chromatography with mass spectrometry or flame ionization detection [18-21].

Diet is considered to be the greatest source of human exposure to furfuryl alcohol and $\beta$-myrcene. However, unlike the furanic compounds furan, 5-hydroxymethylfurfural (HMF), and furfural, and other food and beverage constituents such as ethanol, ethyl carbamate, or polycyclic aromatic hydrocarbons for which extensive occurrence data is available [22-26], there is a paucity of information on human dietary exposure to furfuryl alcohol and $\beta$-myrcene. The two agents are due for assessment as to their carcinogenicity by the International Agency for Research in Cancer (IARC) expert working group in their meeting to be held in June 2017. This study aims to provide an overview of the occurrence of furfuryl alcohol and $\beta$-myrcene in foods and beverages.

\section{Materials and Methods}

Occurrence data on furfuryl alcohol and $\beta$-myrcene were searched in the following databases: PubMed, Toxnet and ChemIDplus (U.S. National Library of Medicine, Bethesda, MD, USA), Web of Science (Clarivate Analytics, Philadelphia, PA, USA), and IPCS/INCHEM (International Programme on Chemical Safety/Chemical Safety Information from Intergovernmental Organizations, WHO, Geneva, Switzerland). Reference lists of all articles were hand-searched for relevant studies not included in the original search results. The literature sources (including abstracts) were evaluated using Mendeley (Mendeley Inc., New York, NY, USA). By manual screening, relevant articles were identified and ordered in full-text. No unpublished study was identified.

Additional data on the occurrence of furfuryl alcohol was also obtained from in-house analysis of 30 coffee (roasted coffee as beans, powder, or pods), 15 bread, 20 wine, and 50 alcoholic spirit samples (whiskey, brandy, and rum) submitted to our laboratory in the context of official control using nuclear magnetic resonance spectroscopy (NMR) [27]. For this, spectra previously acquired for other purposes were re-quantified for furfuryl alcohol. The coffee samples were analysed according to Monakhova et al. [28]. Quantification was conducted using the integral of the $\mathrm{CH}$ group at the $\mathrm{C} 5$ resonance of furfuryl alcohol $(\delta 7.47-7.35 \mathrm{ppm})$ in relation to the internal standard 1,2,4,5-tetrachloro-3-nitrobenzene ( $\delta$ 7.75-7.72 ppm). Quantification was conducted using TopSpin 3.2 (BrukerBioSpin $\mathrm{GmbH}$, Rheinstetten, Germany) and Mestrenova V. 11.0.2 (Mestrelab Research, Santiago de Compostela, Spain) [29]. For evaluation of spirits, the NMR method of Monakhova et al. [27] was applied. The NMR methods achieved a limit of detection (LOD) of $3.2 \mathrm{mg} / \mathrm{L}$ and limit of quantification (LOQ) of $8.6 \mathrm{mg} / \mathrm{L}$. The results of NMR must be interpreted as semi-quantitative, because only one single non-overlapped signal of furfuryl alcohol was available for quantification. Identity was confirmed by spiking with pure furfuryl alcohol to authentic samples, but co-occurrence of compounds with a similar chemical shift cannot be completely excluded. The statistical parameters of mean, median, and percentiles (90th, 95th, 97.5th, and 99th) were used to describe the occurrence data. Similar NMR analysis of $\beta$-myrcene (e.g., in hops) was not possible due to considerable matrix interferences of all relevant signals. The concentration of $\beta$-myrcene in compounded products such as beer was below the detection limit of NMR.

\section{Results}

This study summarizes the occurrence of furfuryl alcohol and $\beta$-myrcene in various foods and beverages. Limited studies on $\beta$-myrcene (7) were observed compared to 19 studies for furfuryl alcohol. Meta-analysis was not possible due to the sparsity of studies for each type of food and beverage. The occurrence of furfuryl alcohol was recorded in many foods and beverages that had 
been subjected to thermal processing. The literature studies summarized in Table 1 were extended by inclusion of original results from our own analyses on furfuryl alcohol in 30 coffee, 15 bread, 20 wine, and 50 aged alcoholic spirit samples. From these, only coffee samples were positive (average furfuryl alcohol content of $251 \mathrm{mg} / \mathrm{kg}$ ), while all other samples were below the detection limit of the method. A typical spectrum of a coffee sample is shown in Figure 1.

Out of the seven studies on $\beta$-myrcene, four were in hops and related products, while two were in beer, and the final reference reported about general use levels in various foods/beverages. Chewing gum, gelatin, beer, and hops were suggested as products with high concentration of $\beta$-myrcene. The studies are summarized in Table 2.

Table 1. Furfuryl alcohol content in various foods and beverages.

\begin{tabular}{|c|c|c|c|c|c|c|c|c|c|}
\hline Category [Reference] & $\mathbf{N}$ & \multicolumn{7}{|c|}{ Furfuryl Alcohol Concentration } & Units $^{a}$ \\
\hline Roasted coffee/This study & 30 & 251 & 243 & 342 & 392 & 402 & 406 & 408 & $\mathrm{mg} / \mathrm{kg}$ \\
\hline Bread/This study & 15 & $<\mathrm{LOD}^{\mathrm{b}}$ & - & - & - & - & - & - & $\mathrm{mg} / \mathrm{kg}$ \\
\hline Wine/This study & 20 & $<\mathrm{LOD}^{\mathrm{b}}$ & - & - & - & - & - & - & $\mathrm{mg} / \mathrm{L}$ \\
\hline Spirits/This study & 50 & $<\mathrm{LOD}^{\mathrm{b}}$ & - & - & - & - & - & - & $\mathrm{mg} / \mathrm{L}$ \\
\hline Baked goods [9] ${ }^{\mathrm{d}}$ & - & 110 & - & - & - & - & - & - & ppm \\
\hline Spirits [9] ${ }^{\mathrm{d}}$ & - & 10 & - & - & - & - & - & - & ppm \\
\hline Candy [9] d & - & 59 & - & - & - & - & - & - & ppm \\
\hline Ice cream/ices [9] $\mathrm{d}$ & - & 88 & - & - & - & - & - & - & ppm \\
\hline Beverages [9] d & - & 19 & - & - & - & - & - & - & ppm \\
\hline Breaded fish products [17] & 4 & 10.3 & 8.8 & 16 & 18 & 18 & 19 & 19 & $\mathrm{mg} / \mathrm{kg}$ \\
\hline Wine [30] & 6 & 1.51 & 0.89 & 1.57 & 1.60 & 1.62 & 1.63 & 1.64 & $\mathrm{mg} / \mathrm{L}$ \\
\hline Vinegar [31] ${ }^{\mathrm{c}}$ & 27 & 0.35 & 0.28 & 0.58 & 0.59 & 0.59 & 0.59 & 0.59 & $\mathrm{mg} / \mathrm{L}$ \\
\hline Vinegar [32] ${ }^{\mathrm{c}}$ & 9 & 0.34 & 0.28 & 0.58 & 0.59 & 0.59 & 0.59 & 0.59 & $\mathrm{mg} / \mathrm{L}$ \\
\hline Coffee [33] & 7 & 49 & 49 & 64 & 67 & 68 & 69 & 70 & $\mathrm{mg} / \mathrm{kg}$ \\
\hline Instant coffee [34] & 1 & 267 & - & - & - & - & - & - & $\mathrm{mg} / \mathrm{kg}$ \\
\hline Roasted coffee [34] & 1 & 564 & - & - & - & - & - & - & $\mathrm{mg} / \mathrm{kg}$ \\
\hline Pineapple juice [34] & 1 & 8.3 & - & - & - & - & - & - & $\mathrm{mg} / \mathrm{L}$ \\
\hline Rice cakes [35] & 2 & $2,2.3$ & - & - & - & - & - & 2.3 & $\mathrm{mg} / \mathrm{kg}$ \\
\hline Bread [36] & 1 & 187 & - & - & - & - & - & - & $\mathrm{mg} / \mathrm{kg}$ \\
\hline
\end{tabular}

${ }^{a}$ The ambiguous unit ppm was interpreted as $\mathrm{mg} / \mathrm{L}$ for liquids/beverages and as $\mathrm{mg} / \mathrm{kg}$ for solid foods. b All samples evaluated (spirits types whiskey, rum, brandy as well as various wines and breads) were below the limit of detection (LOD; $3.2 \mathrm{mg} / \mathrm{L}$ ). ${ }^{c}$ Studies from the same research group with probably overlapping data. d Number of samples not provided. The data are suggested as being "usual concentrations" found in these food/beverage types. 


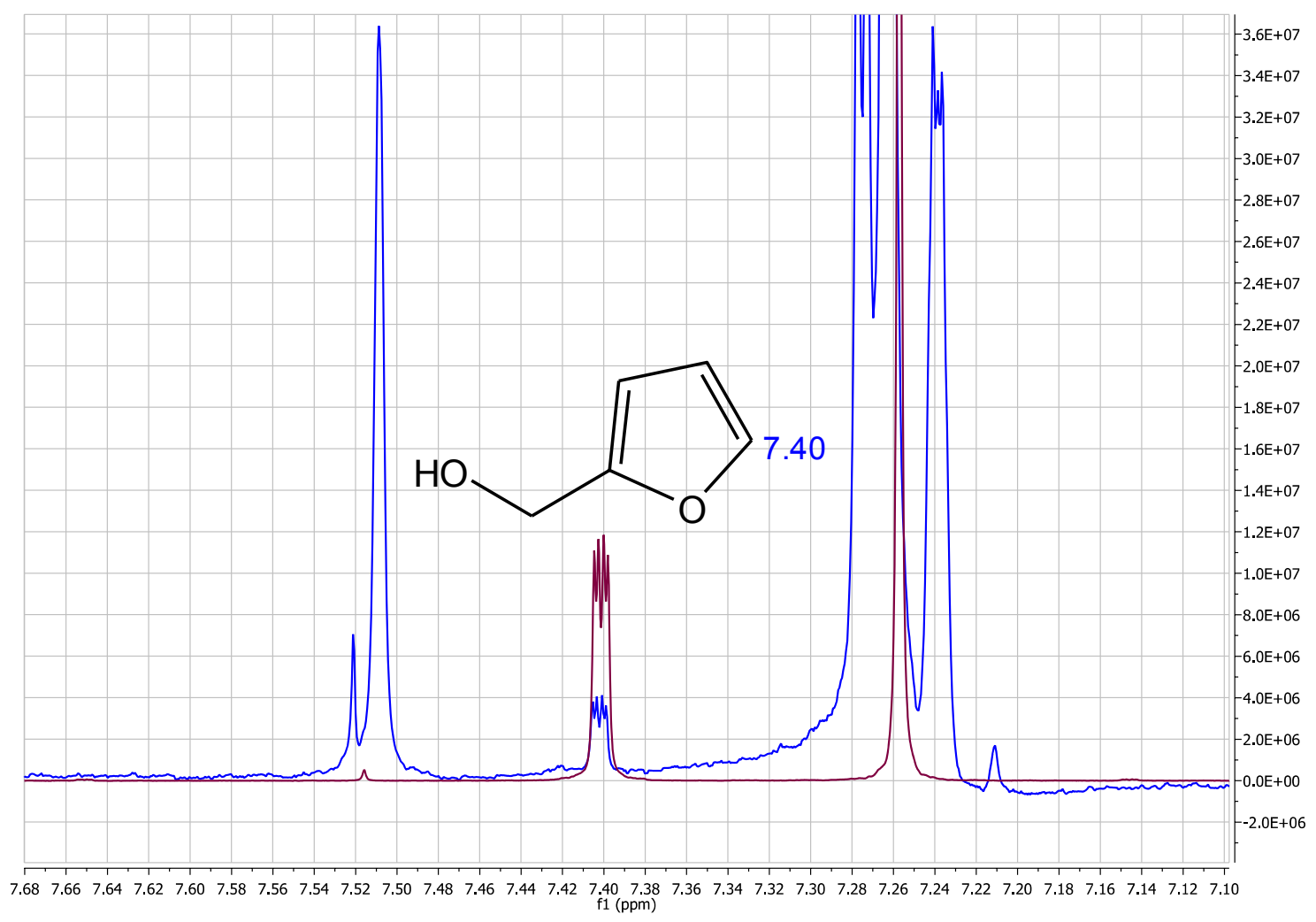

Figure 1. NMR spectra of an authentic coffee sample (blue line) containing $408 \mathrm{mg} / \mathrm{kg}$ of furfuryl alcohol compared to the reference standard (red line).

Table 2. $\beta$-Myrcene content in various matrices.

\begin{tabular}{cccccccccc}
\hline \multirow{2}{*}{ Matrix [Reference] } & \multirow{2}{*}{$\mathbf{N}$} & \multicolumn{7}{c}{ Concentration } & \multirow{2}{*}{ Units } \\
\cline { 3 - 9 } & & Mean & Median & P90 & P95 & P97.5 & P99 & Maximum & \\
\hline Hops oil [18] & 4 & 479 & 424 & 776 & 852 & 890 & 912 & 927 & $\mathrm{mg} / \mathrm{L}$ \\
Hops [42] & 12 & 5489 & 4804 & 8580 & 9450 & 9972 & 10,285 & 10,494 & $\mathrm{mg} / \mathrm{kg}$ \\
Hops [43] & 8 & 15 & 14 & 28 & 29 & 29 & 29 & 29 & $\mu \mathrm{\mu g} / \mathrm{L}$ \\
Hops [44] & 12 & 1082 & 705 & 2369 & 2795 & 3043 & 3191 & 3290 & $\mathrm{mg} / \mathrm{kg}$ \\
Pilsner beer [45] & 2 & 46,79 & - & - & - & - & - & 79 & $\mu \mathrm{g} / \mathrm{L}$ \\
Beer [46] & 2 & $0.5,0.6$ & - & - & - & - & - & 0.6 & $\mu \mathrm{g} / \mathrm{L}$ \\
Alcoholic beverages [47] $^{\mathrm{b}}$ & - & 1.1 & - & - & - & - & - & - & $\mathrm{mg} / \mathrm{L}$ \\
Baked goods [47] $^{\mathrm{b}}$ & - & 10 & - & - & - & - & - & - & $\mathrm{mg} / \mathrm{kg}$ \\
Chewing gum [47] $^{\mathrm{b}}$ & - & 116 & - & - & - & - & - & - & $\mathrm{mg} / \mathrm{kg}$ \\
Condiment [47] $^{\mathrm{b}}$ & - & 5 & - & - & - & - & - & - & $\mathrm{mg} / \mathrm{kg}$ \\
Frozen dairy [47] $^{\mathrm{b}}$ & - & 12 & - & - & - & - & - & - & $\mathrm{mg} / \mathrm{kg}$ \\
Gelatin, pudding [47] $^{\mathrm{b}}$ & - & 20 & - & - & - & - & - & - & $\mathrm{mg} / \mathrm{kg}$ \\
Meat products [47] $^{\mathrm{b}}$ & - & 5 & - & - & - & - & - & - & $\mathrm{mg} / \mathrm{kg}$ \\
Non-alcoholic beverages [47] $^{\mathrm{b}}$ & - & 8 & - & - & - & - & - & - & $\mathrm{mg} / \mathrm{L}$ \\
Soft candy [47] $^{\mathrm{b}}$ & - & 6 & - & - & - & - & - & - & $\mathrm{mg} / \mathrm{kg}$ \\
\hline
\end{tabular}

${ }^{a}$ The ambiguous unit ppm was interpreted as $\mathrm{mg} / \mathrm{L}$ for liquids/beverages and as $\mathrm{mg} / \mathrm{kg}$ for solid food. ${ }^{\mathrm{b}}$ Number of samples not provided. The data are suggested as being "usual concentrations" found in these food/beverage types.

\section{Discussion}

\subsection{Occurrence of Furfuryl Alcohol}

The concentration of furfuryl alcohol was highest in coffee (beans $564 \mathrm{mg} / \mathrm{kg}$ and $267 \mathrm{mg} / \mathrm{kg}$ in instant coffee powder). Our new data on coffee with an average of $251 \mathrm{mg} / \mathrm{kg}$ and a maximum of $408 \mathrm{mg} / \mathrm{kg}$ corresponds well to the previous data. Green coffee is free of furfuryl alcohol (confirmed in eight samples with non-detectable levels), so the occurrence of furfuryl alcohol in coffee has been 
confirmed as being attributable to the roasting process [5]. This observation parallels the high content of furan found in coffee compared to other foods [24]. Other thermally processed foods, such as bread $(187 \mathrm{mg} / \mathrm{kg})$, baked goods (110 mg/ $\mathrm{kg}$ ), ice cream/ices $(88 \mathrm{mg} / \mathrm{kg})$, and fried fish (about $10 \mathrm{mg} / \mathrm{kg}$ ) were also found to contain detectable amounts of furfuryl alcohol. Among beverages, higher concentrations of furfuryl alcohol arising from aging in oak barrels [30] were found in spirits $(10 \mathrm{mg} / \mathrm{L})$ than in wine $(1.5-3.4 \mathrm{mg} / \mathrm{L})$. However, the content was lower compared to bread, baked goods, fish, and coffee. Relatively lower concentrations (less than $1 \mathrm{mg} / \mathrm{kg}$ ) were observed in palm sugar, chips, popcorns, sweet potatoes, and vinegar. The variation in the concentration of furfuryl alcohol in the foods/beverages may be related to the type of raw materials and processing conditions used. The Joint FAO/WHO Expert Committee on Food Additives (JECFA) set a group acceptable daily intake (ADI) of 0-0.5 mg/ $\mathrm{kg}$ body weight for furfuryl alcohol, and suggested the compound as being of no safety concern at current levels of intake when used as a flavouring agent [48]. Despite the concentrations reported here being low for a majority of individual foods and beverages, a cumulative amount of furfuryl alcohol may be ingested from consuming a combination of different foods and beverages. According to the National Toxicology Program (NTP) report [49], exposure of male mice to $32 \mathrm{ppm}$ (equivalent to $60 \mathrm{mg} / \mathrm{kg}$ bw/day [50]) of furfuryl alcohol was found to induce tumours of renal tubular epithelium. The postulated mechanism of carcinogenicity of furfuryl alcohol is through activation by sulfotransferases resulting in the formation of a 2-methylfuranyl-DNA adduct [50,51]. According to estimation from the typical intake levels of the food items listed in Table 1, concentrations of toxicological concern are probably not reached. However, food legislation demands to reduce food contaminants as low as reasonably achievable (ALARA principle). More data are clearly necessary to provide exposure estimations and risk assessment for this compound.

\subsection{Occurrence of $\beta$-Myrcene}

A majority of the studies on $\beta$-myrcene are qualitative, and the few quantitative data were focusing on hops and beers, despite the widespread occurrence of myrcene in many plants that are used in foods and beverages. Hop oil and chewing gum were found to contain the highest content of $\beta$-myrcene compared to other products. The low concentration of $\beta$-myrcene in beers is plausible, since there is a very variable extraction of $\beta$-myrcene from hops to beer postulated to be in the range of $0.5 \%-5.6 \%$ from cones and $8.4 \%-25.8 \%$ from pellets [52], and hops contain other volatile components such linanool, humulene, and $\alpha$-terpineol in higher proportions than $\beta$-myrcene. Additionally, $\beta$-myrcene may be destroyed during the heating processes, and thus a low level is expected in the final beer. The NTP report links $\beta$-myrcene with neoplasms of the kidney in male rats and liver cancer in male mice [53]. The daily per capita intake (eaters only) for $\beta$-myrcene was estimated as being $164 \mu \mathrm{g}$ corresponding to $3 \mu \mathrm{g} / \mathrm{kg}$ bw [54].

\section{Conclusions}

Consistent with the relatively high amounts of furfuryl alcohol (above $10 \mathrm{mg} / \mathrm{kg}$ ) observed in coffee, baked goods, bread, fish, and some spirit drinks, monitoring these items for furfuryl alcohol is advisable for comprehensive estimation of exposures and the risk of these foods, while more research on the occurrence of $\beta$-myrcene in foods and beverages in general is required for meaningful risk assessment.

Acknowledgments: Andreas Scharinger is thanked for excellent technical assistance for the NMR work. Alex Okaru is indebted to the DAAD (German Academic Exchange Service) programme funding No. 5250960 for the scholarship award.

Author Contributions: All authors contributed equally to this study.

Conflicts of Interest: The authors declare no conflict of interest. 


\section{References}

1. Monakhova, Y.B.; Lachenmeier, D.W. The Margin of Exposure of 5-Hydroxymethylfurfural (HMF) in alcoholic beverages. Environ. Health Toxicol. 2012, 27, e2012016. [CrossRef] [PubMed]

2. Martins, S.I.; Jongen, W.M.; Boekel, M.A. A review of Maillard reaction in food and implications to kinetic modelling. Trends Food Sci. Technol. 2001, 11, 364-373. [CrossRef]

3. Vanderhaegen, B.; Delvaux, F.; Daenen, L.; Verachtert, H.; Delvaux, F.R. Aging characteristics of different beer types. Food Chem. 2007, 103, 404-412. [CrossRef]

4. Wang, Y.; Kays, S.J. Contribution of volatile compounds to the characteristic aroma of baked "Jewel" sweetpotatoes. J. Amer. Soc. Hort. Sci. 2000, 125, 638-643.

5. Swasti, Y.R.; Murkovic, M. Characterization of the polymerization of furfuryl alcohol during roasting of coffee. Food Funct. 2012, 3, 965-969. [CrossRef] [PubMed]

6. Pérez-Prieto, L.J.; López-Roca, J.M.; Martínez-Cutillas, A.; Pardo-Mínguez, F.; Gómez-Plaza, E. Extraction and formation dynamic of oak-related volatile compounds from different volume barrels to wine and their behavior during bottle storage. J. Agric. Food Chem. 2003, 51, 5444-5449. [CrossRef] [PubMed]

7. Spillman, P.J.; Pollnitz, A.P.; Liacopoulos, D.; Pardon, K.H.; Sefton, M.A. Formation and degradation of furfuryl alcohol, 5-Methylfurfuryl alcohol, vanillyl alcohol, and their ethyl ethers in barrel-aged wines. J. Agric. Food Chem. 1998, 46, 657-663. [CrossRef] [PubMed]

8. Mochizuki, N.; Kitabatake, K. Analysis of 1-(2-furyl)propane-1,2-diol, a furfural metabolite in beer. J. Ferment. Bioeng. 1997, 83, 401-403. [CrossRef]

9. National Research Council (U.S.). Chemicals Used in Food Processing; National Academy of Sciences: Washington DC, USA, 1965.

10. Paumgartten, F.J.; De-Carvalho, R.R.; Souza, C.A.; Madi, K.; Chahoud, I. Study of the effects of beta-myrcene on rat fertility and general reproductive performance. Braz. J. Med. Biol. Res. 1998, 31, 955-965. [CrossRef] [PubMed]

11. Mohamed Hanaa, A.R.; Sallam, Y.I.; El-Leithy, A.S.; Aly, S.E. Lemongrass (Cymbopogon citratus) essential oil as affected by drying methods. Ann. Agric. Sci. 2012, 57, 113-116. [CrossRef]

12. Lachenmeier, K.; Musshoff, F.; Madea, B.; Lachenmeier, D.W. Application of experimental design to optimise solid-phase microextraction of orange juice flavour. Electron. J. Environ. Agric. Food Chem. 2006, 5, 1380-1388.

13. Behr, A.; Johnen, L. Myrcene as a natural base chemical in sustainable chemistry: A critical review. ChemSusChem 2009, 2, 1072-1095. [CrossRef] [PubMed]

14. Vázquez, L.; Verdú, A.; Miquel, A.; Burló, F.; Carbonell-Barrachina, A.A. Changes in physico-chemical properties, hydroxymethylfurfural and volatile compounds during concentration of honey and sugars in Alicante and Jijona turron. Eur. Food Res. Technol. 2007, 225, 757-767. [CrossRef]

15. Park, D.; Maga, J.A. Identification of key volatiles responsible for odour quality differences in popped popcorn of selected hybrids. Food Chem. 2006, 99, 538-545. [CrossRef]

16. Pérez-Palacios, T.; Petisca, C.; Melo, A.; Ferreira, I.M. Quantification of furanic compounds in coated deep-fried products simulating normal preparation and consumption: Optimisation of HS-SPME analytical conditions by response surface methodology. Food Chem. 2012, 135, 1337-1343. [CrossRef] [PubMed]

17. Pérez-Palacios, T.; Petisca, C.; Henriques, R.; Ferreira, I.M. Impact of cooking and handling conditions on furanic compounds in breaded fish products. Food Chem. Toxicol. 2013, 55, 222-228. [CrossRef] [PubMed]

18. Van Opstaele, F.; De Causmaecker, B.; Aerts, G.; De Cooman, L. Characterization of novel varietal floral hop aromas by headspace solid phase microextraction and gas chromatography-mass spectrometry/olfactometry. J. Agric. Food Chem. 2012, 60, 12270-12281. [CrossRef] [PubMed]

19. Gonçalves, J.; Figueira, J.; Rodrigues, F.; Câmara, J.S. Headspace solid-phase microextraction combined with mass spectrometry as a powerful analytical tool for profiling the terpenoid metabolomic pattern of hop-essential oil derived from Saaz variety. J. Sep. Sci. 2012, 35, 2282-2296. [CrossRef] [PubMed]

20. Roberts, M.T.; Dufour, J.P.; Lewis, A.C. Application of comprehensive multidimensional gas chromatography combined with time-of-flight mass spectrometry (GC x GC-TOFMS) for high resolution analysis of hop essential oil. J. Sep. Sci. 2004, 27, 473-478. [CrossRef] [PubMed]

21. Kishimoto, T.; Wanikawa, A.; Kono, K.; Shibata, K. Comparison of the odor-active compounds in unhopped beer and beers hopped with different hop varieties. J. Agric. Food Chem. 2006, 54, 8855-8861. [CrossRef] [PubMed] 
22. Lachenmeier, D.W.; Przybylski, M.C.; Rehm, J. Comparative risk assessment of carcinogens in alcoholic beverages using the margin of exposure approach. Int. J. Cancer 2012, 131, E995-E1003. [CrossRef] [PubMed]

23. Lachenmeier, D.W. Carcinogens in Food: Opportunities and Challenges for Regulatory Toxicology. Open Toxicol. J. 2009, 3, 30-34. [CrossRef]

24. Waizenegger, J.; Winkler, G.; Kuballa, T.; Ruge, W.; Kersting, M.; Alexy, U.; Lachenmeier, D.W. Analysis and risk assessment of furan in coffee products targeted to adolescents. Food Addit. Contam. 2012, 29, $19-28$. [CrossRef] [PubMed]

25. European Food Safety Authority. Polycyclic Aromatic Hydrocarbons in Food. EFSA J. 2008, 724, 1-114.

26. Singh, L.; Varshney, J.G.; Agarwal, T. Polycyclic aromatic hydrocarbons' formation and occurrence in processed food. Food Chem. 2016, 199, 768-781. [CrossRef] [PubMed]

27. Monakhova, Y.B.; Schäfer, H.; Humpfer, E.; Spraul, M.; Kuballa, T.; Lachenmeier, D.W. Application of automated eightfold suppression of water and ethanol signals in 1H NMR to provide sensitivity for analyzing alcoholic beverages. Magn. Reson. Chem. 2011, 49, 734-739. [CrossRef] [PubMed]

28. Monakhova, Y.B.; Ruge, W.; Kuballa, T.; Ilse, M.; Winkelmann, O.; Diehl, B.; Thomas, F.; Lachenmeier, D.W. Rapid approach to identify the presence of Arabica and Robusta species in coffee using $1 \mathrm{H}$ NMR spectroscopy. Food Chem. 2015, 182, 178-184. [CrossRef] [PubMed]

29. Bernstein, M.A.; Sýkora, S.; Peng, C.; Barba, A.; Cobas, C. Optimization and automation of quantitative NMR data extraction. Anal. Chem. 2013, 85, 5778-5786. [CrossRef] [PubMed]

30. Carrillo, J.D.; Garrido-López, Á.; Tena, M.T. Determination of volatile oak compounds in wine by headspace solid-phase microextraction and gas chromatography-mass spectrometry. J. Chromatogr. A 2006, 1102, 25-36. [CrossRef] [PubMed]

31. Morales, M.L.; Benitez, B.; Troncoso, A.M. Accelerated aging of wine vinegars with oak chips: Evaluation of wood flavour compounds. Food Chem. 2004, 88, 305-315. [CrossRef]

32. Tesfaye, W.; Morales, M.L.; Benítez, B.; García-Parrilla, M.C.; Troncoso, A.M. Evolution of wine vinegar composition during accelerated aging with oak chips. Anal. Chim. Acta 2004, 513, 239-245. [CrossRef]

33. Petisca, C.I. Furanic Compounds in Food Products: Assessment and Mitigation Strategies. Ph.D. Thesis, Universidade Do Porto, Porto, Portugal, 2013.

34. Golubkova, T. Bildung von Potentiell Toxischen Furanderivaten in Lebensmitteln. Masters Thesis, TU Graz, Austria, 2011.

35. Moon, J.K.; Shibamoto, T. Role of roasting conditions in the profile of volatile flavor chemicals formed from coffee beans. J. Agric. Food Chem. 2009, 57, 5823-5831. [CrossRef] [PubMed]

36. Jensen, S.; Ostdal, H.; Skibsted, L.H.; Thybo, A.K. Antioxidants and shelf life of whole wheat bread. J. Cereal Sci. 2011, 53, 291-297. [CrossRef]

37. Vázquez-Araújo, L.; Enguix, L.; Verdú, A.; García-García, E.; Carbonell-Barrachina, A.A. Investigation of aromatic compounds in toasted almonds used for the manufacture of turrón. Eur. Food Res. Technol. 2008, 227, 243-254. [CrossRef]

38. Karagül-Yüceer, Y.; Cadwallader, K.R.; Drake, M.A. Volatile flavor components of stored nonfat dry milk. J. Agric. Food Chem. 2002, 50, 305-312. [CrossRef]

39. Buttery, R.G.; Ling, L.C. Additional Studies on Flavor Components of Corn Tortilla Chips. J. Agric. Food Chem. 1998, 46, 2764-2769. [CrossRef]

40. Bonvehí, J.S. Investigation of aromatic compounds in roasted cocoa powder. Eur. Food Res. Technol. 2005, 221, 19-29. [CrossRef]

41. Ho, C.W.; Aida, W.M.W.; Maskat, M.Y.; Osman, H. Changes in volatile compounds of palm sap (Arenga pinnata) during the heating process for production of palm sugar. Food Chem. 2007, 102, 1156-1162. [CrossRef]

42. Aberl, A.; Coelhan, M. Determination of volatile compounds in different hop varieties by headspace-trap GC/MS-In comparison with conventional hop essential oil analysis. J. Agric. Food Chem. 2012, 60, 2785-2792. [CrossRef]

43. Mitter, W.; Cocuzza, S. Dry Hopping-A Study of Various Parameters Consequences of the Applied Dosing Method. Available online: http://hopsteiner.com/wp-content/uploads/2016/03/3_Dry-HoppingA-Study-of-Various-Parameters.pdf (accessed on 10 September 2016).

44. Peacock, V.E.; Deinzer, M.L. Chemistry of hop aroma in beer. J. Am. Soc. Brew. Chem 1979, 39, $136-141$. 
45. Schmidt, C.; Biendl, M. Headspace Trap GC-MS analysis of hop aroma compounds in beer. BrewingScience 2016, 69, 9-15.

46. Mikyška, A.; Olšovská, J. Czech Research and Development in the Field of Brewing Raw Materials. Available online: http://www.hmelj-giz.si/ihgc/doc/LdVBS-RIBM_raw_materials_research.pdf (accessed on 11 September 2016).

47. Burdock, G.A. Fenaroli's Handbook of Flavor Ingredients; CRC Press: Boca Raton, FL, USA, 2004.

48. World Health Organization (WHO). Evaluation of Certain Food Additives and Contaminants; 55th report of the Joint FAO/WHO Expert Committee on Food Additives; WHO: Geneva, Switzerland, 2001.

49. National Toxicology Program (NTP). Technical Report on the Toxicology and Carcinogenesis Studies of Furfuryl Alcohol (CAS NO. 98-00-0) in F344/N Rats and B6C3F1 Mice (Inhalational Studies). NTP TR 482. NIH Publication No. 99-3972; National Toxicology Program: Research Triangle Park, NC, USA, 1999.

50. Sachse, B.; Meinl, W.; Sommer, Y.; Glatt, H.; Seidel, A.; Monien, B.H. Bioactivation of food genotoxicants 5-hydroxymethylfurfural and furfuryl alcohol by sulfotransferases from human, mouse and rat: A comparative study. Arch. Toxicol. 2016, 90, 137-148. [CrossRef] [PubMed]

51. Sachse, B.; Meinl, W.; Glatt, H.; Monien, B.H. The effect of knockout of sulfotransferases $1 \mathrm{a} 1$ and $1 \mathrm{~d} 1$ and of transgenic human sulfotransferases 1A1/1A2 on the formation of DNA adducts from furfuryl alcohol in mouse models. Carcinogenesis 2014, 35, 2339-2345. [CrossRef] [PubMed]

52. Wolfe, P.H. A Study of Factors Affecting the Extraction of Flavor When Dry Hopping Beer. Masters Thesis, Oregon State University, Corvallis, OR, USA, 2012.

53. National Toxicology Program (NTP). Technical Report on the Toxicology and Carcinogenesis Studies of $\beta$-Myrcene (CAS NO. 123-35-3) in F344/N Rats and B6C3F1 Mice. NTP TR 557. NIH Publication No. 09-5898; National Toxicology Program: Reseach Triangle Park, NC, USA, 2011.

54. Adams, T.B.; Gavin, C.L.; McGowen, M.M.; Waddell, W.J.; Cohen, S.M.; Feron, V.J.; Marnett, L.J.; Munro, I.C.; Portoghese, P.S.; Rietjens, I.M.C.M.; Smith, R.L. The FEMA GRAS assessment of aliphatic and aromatic terpene hydrocarbons used as flavor ingredients. Food Chem. Toxicol. 2011, 49, 2471-2494. [CrossRef] [PubMed]

(c) 2017 by the authors. Licensee MDPI, Basel, Switzerland. This article is an open access article distributed under the terms and conditions of the Creative Commons Attribution (CC BY) license (http:/ / creativecommons.org/licenses/by/4.0/). 